スリランカ南半部の海岸地形と海水準変化に関する研究

藤 原 健 蔵* ジナダサ カトゥポタ*

\title{
Coastal Geomorphology and Sea Level Changes in the Southern Part of Sri Lanka
}

Kenzo Fujiwara and Jinadasa Katupotha

\section{I. 目 的}

日本に抒ける完新世海水準変動の研究は, ${ }^{14} \mathrm{C}$ 年代資料の集積と精細な地形学的・微古生物学的 検討によって $1 \mathrm{~m}$ のオーダーで論じられるように なってきた。しかし，その際絶えずつきまとうの は局所的な地款变動の取り扱いであって，その扱 い方しだいでは導き出される結論が大きく変って くる状況である（井関 1978）。

本研究はこうした認識から, 局所的な地殼変動 の影響の少ない海外の安定地域において ${ }^{14} \mathrm{C}$ 年代 の測定試料を採集し，完新世海水準変動研究の基 礎資料を得ようとするものである。

\section{II. 調查地域の概観}

調查対象国のスリランカはインド亜大陸南端の 大陸棚に浮かぶ安定地域であり, 延長 $1,700 \mathrm{~km}$ にわたるその海岸線は比較的単純な形態を示すも のの, およそ次の諸特徵を有する。

(1) 南西部から南部をへて 南東部に至る 海岸 （全延長の $36 \%$ ）は島の所々に小湾入を有する岩 石海岸である。これは島の中央やや南寄りに海抜 $1,000 \mathrm{~m}$ 以上の中央高地があり, その南側から海 岸まで丘陵性山地が横たわるからである。これに 対して, 中央高地の北側には低位準平原（第一準 平原）が広がり，インド亜大陸との海峡, Mannar・Palk 両湾に向かって緩やかに傾く。この ため, 島の西海岸と北東海岸（合わせて全延長の 33\%）は砂浜海岸となっており, また両者にはさ まれた北西海岸は三角州性の海岸平野（全延長の 25\%）となっている。

（2）スリランカでは降水に 明膫な 季節的リズ
ムがあり，それによって自然地域は wet zone(南 西部, 全島の $1 / 4)$ と dry zone に 2 分される。こ れによく対応して海岸地形も特徴づけられてい る。例えば砂丘の発達状況についてみると, 年降 水量 $2,000 \mathrm{~mm}$ 以上の wet zone では植被が厚く 砂丘を欠くが, $2,000 \mathrm{~mm} \sim 1,300 \mathrm{~mm} の$ dry zone では浜堤上に低い砂丘がのり,さらに 1,300 $\mathrm{mm}$ 以下では比高 $5 \mathrm{~m}$ 以上の大型砂丘が連続的 に形成されている。

（3）スリランカの沿岸海域は 南西モンスーン ならびに北東モンスーンによってたえず強い波浪 に洗われ，サンゴの成長がすこぶるよいとされて いる。特に岩石海岸が続く南西部の Galle 付近 および北東部の Koddiyar 湾付近においてサンゴ 礁がよく発達し, また北端 Jaffna 付近の石灰岩 海岸にもサンゴ礁がみられる。Colombo 付近の 西海岸および Kalmunai 付近の東海岸は砂丘を 欠く砂浜海岸であるが，この一帯に発達するビー チロックによって海岸侵食の害を免れている。

\section{III. 現地調査および ${ }^{14} \mathrm{C}$ 年代測定}

現地調查は 1980 年 7 月 29 日〜 8 月 21 日の 24 日 間, 藤原および J. カトゥポタによって行われた。 数年前から Jaffna 市を中心とする北部一帯がタ ミル人過激派のゲリラ活動によって立ち入り禁止 になっているので, 当初より調查計画からはずし た。調查車輛 1 台（ドライバーおよび補助付）を チャーターし, 在コロンボ日本企業およびコロン ボ大学から測量・簡易ボーリング 器具等を借用 し, 西海岸の Puttalam から Chilaw, Negombo, Colombo, 南西海岸の Hikkaduwa, Galle, 南海 岸の Tangalla, Ambalantota, Kirinda に至る範

* 広島大学文学部地理学教室 Department of Geography, University of Hiroshima 
囲を調查した。数条の浜堤列が配列する西海岸で は自動レベルによる横断測量と土層調查に重点を 置き，サンゴ礁の発達する南海岸では年代測定用 の試料の採集に調査の重点を置いた。

採集試料は日本に持ち帰り, 広島大学地理学教 室の低バックグランド液体シンチレーションカン ター（メタノール法）にかけて ${ }^{14} \mathrm{C}$ 年代の測定を した。現在までに測定を 終えた試料数は 20 であ る。これまでスリランカで報告された ${ }^{14} \mathrm{C}$ 年代は 数件にすぎなかったので, 本研究によってその数 は一挙に増えたことになる。

\section{IV. 研究の成果}

(1) Chilaw-Negembo-Colombo (西海岸)

スリランカの地形図には等高線が画かれていな い。幸い空中写真が得られたので, 判読して地形 学図を作成した。本地域では地形の帯状配列が明 瞭であり，陸側からラテライト性風化殼を有して 海側に緩斜する低位準平原, その西縁を薄く覆つ て発達する更新世海成段丘，ラグーンおよびそれ を埋めて生成したマングローブ湿地・塩性（感 潮）湿地・泥質平地等の完新世低平地および，そ れらを内側に閉じこめて細長く北方にのびる浜堤 群である。

3 測線で行った水準測量によれば，更新世海成 段丘の高度は海抜 $6 \sim 10 \mathrm{~m}$ ，形成時期は具体的な 証拠を得ていないが，段丘面の開析状況，砂層上 部の赤色化等から更新世と推定しておく。

完新世浜堤群は新旧 2 列に分けられる。古い方 は海抜 $4 \sim 5 \mathrm{~m}$ ，西海岸のほぼ全域に発達する。 波打際には海方に緩く傾く厚さ60 $80 \mathrm{~cm}$ の潮間 帯ビーチロックが露出する。調查時（8月）に は，風浪がビーチロック前面の小崖で砕け，砕け 波がその表面全体を洗っていたが，北東モンスー ン期にはビーチロック全体が海面上に露出し，そ の前面に現われた砂浜から漁民が小舟を漕ぎ出す という。Negembo 付近の砂鉄質ビーチロックの 表面で採取した 2 枚貝および石灰藻の ${ }^{14} \mathrm{C}$ 年代は

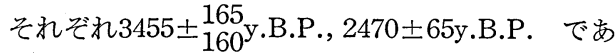
る。なお，Chilaw 湖を閉塞している浜堤では， その基部（海面下 $20 \mathrm{~m}$ 以下）に上記のビーチロッ クより古期のものが伏在する。新しい浜堤は海抜
$2 \sim 4 \mathrm{~m}$, 河口付近や南西からの風浪の弱い所に 局所的に分布する。

西海岸における浜堤の生長とラグーンの埋積過 程は，北微東の走向をもつ基盤起伏，南西モンス ーンによる強い風浪と沿岸流，河川によって大差 のある内陸からの供給土砂等によって支配されて おり，それら支配要因の組合せによって砂浜海岸 に地域差を与えている。

(2) Akurala-Hikkaduwa-Galle（南西海岸） 本地域には小規模ながら裙礁と堡礁タイプのサ ンゴ礁が卓越し，ビーチロックもみられる。Mergner, H. et al. (1974) は Hikkaduwa 中央部 の裾礁を上段（速度 $0 \mathrm{~m}$ 前後），中段 $(0.8 \sim 1.5$ $\mathrm{m})$, 下段 $(3 \sim 4 \mathrm{~m})$, 礁斜面 ( $4 \mathrm{~m}$ 以深) に 分け，現生サンゴは中段に密集して生長している が，上段は石灰藻に膠着されたサンゴ遺骸によっ て構成されているとしている。今回上段表面から 採取した Goniastrea pectinata の ${ }^{14} \mathrm{C}$ 年代は $5105 \pm 60$ y.B.P. である。同裙礁上段に接して高 さ $3 \mathrm{~m}$ の浜堤があり, その内側の湿地にサンゴ 遺骸層が $4 \mathrm{~m}$ の厚さで堆積している。

Hikkaduwa 北部には堡礁タイプの現生サンゴ 礁が発達する。さらに，その北方 $7 \mathrm{~km}$ の Akurala 一帯には同一タイプのサンゴ礁が陸地化し た海岸低地が広がる。旧礁ラグーン内に大量の少 ンゴ遺骸が堆積しており，所々で採掘されて石灰 原料に供されている。2 カ所の採掘ピットで ${ }^{14} \mathrm{C}$ 年代試料を採集した。P 1 では5795 755 y.B.P.

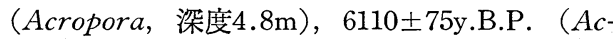
ropora， 樑度 $2.5 \mathrm{~m})$ である。P 2 でも $5995 \pm 85$ y.B.P. (Acropora, 樑度 $3.9 \mathrm{~m}$ ), $5910 \pm 75 \mathrm{y}$. B.P (Porites, 哚度 $3.8 \mathrm{~m}), \quad 5820 \pm 90$ y.B.P. (Echi-

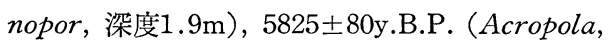
深度 $1.2 \mathrm{~m})$ である。一部に年代の逆転があるが， 全体として $5800 \sim 6100$ 年前ごろに集中している。 現在の礁ラグーン内での Acropora・Parites 等 の生息深度は $2 \sim 3 \mathrm{~m}$ であるので, 当時の海水 準は現海水準ないしそれよりやや高い程度であっ たといえる。当時のラグーン外縁の礁原 Outer barrier の上に現在高さ $2 \sim 3 \mathrm{~m}$ の浜堤がのる が，その前面の波打際にビーチロック（厚さ40 $60 \mathrm{~cm})$ が形成されている。その中から採集した 
Goniastrea の ${ }^{14} \mathrm{C}$ 年代は4075 $475 y$ y.B.P. であ る。

なお, Galle 東方の Habaraduwa でも, 高さ 3 $\mathrm{m}$, 幅 $350 \mathrm{~m}$ の浜堤の背後にサンゴ採掘場があり, その底 (現海水準付近) で得た Acropora の ${ }^{14} \mathrm{C}$ 年代は $5560 \pm 60 \mathrm{y} . \mathrm{B} . P$. である。

(3) Tangalla-Hambantota-Kirinda (南海岸) スリランカの最南端 Dondra 帅をはじめとし て, 南海岸の海食崖下には波食棚に続いて裾礁夕 イプのサンゴ礁がよく発達する。Tangalla 西方 $1 \mathrm{~km}$ の小湾入でも湾内中央に張り出寸岩礁に接 して小規模のサンゴ礁が形成されている。高潮位 付近およびそれより $0.3 \sim 0.4 \mathrm{~m}$ 高い水準で得た サンゴ (Goniastrea) の ${ }^{14} \mathrm{C}$ 年代は，それぞれ

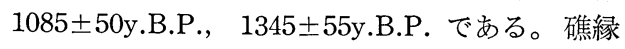
や礁の溝での新しいサンゴの生育は普通であるの で，この程度の差は当然であろう。なお，その 背後の急崖中段（海抜1.3 2.0m) に集積してい たサンゴ (Favites) と貝殼の破片は，それぞれ

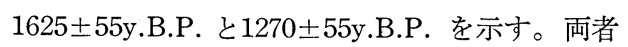
に大きな差があるが，これは恐らくストーム等に よる二次堆積物であり, 特定の旧海水準を示すも のではないと考える。
Tangalla 以東では背後に再び低位準平原が発 達するが，その波状起伏の走向が海岸線に直交し ているので，海岸には盈谷部分が沈水してできた 幅広いラグーン Kalapuwa や湖沼 Lewaya が 並ぶ。それらの岸辺には多くの貝塚が分布し，今 回の調查でも 3 ケ所の貝塚を発見した。それらの ${ }^{14} \mathrm{C}$ 年代は $3050 \pm 95 y$.B.P. (Hambantota 西方 2 $\mathrm{km}$ ), $5775 \pm 110 \mathrm{y}$. B.P. (同西方 $6.5 \mathrm{~km}$ ), $4045 \pm$ $55 \mathrm{y}$. B.P. (同東方 $7.0 \mathrm{~km}$ ) であり, 砂州や砂丘に よる湾口の閉塞過程など古地理変遷を解く手がか りが得られた。

\section{参考文献}

井関弘太郎 (1978)：日本における海水準変動 研究の展望. 地理学評論, 51, 188-195.

Mergner, H. and ScheEr, G. (1974) : The physiographic zonation and the ecological conditions of some South Indian and Ceyon coral reefs. Proc. Second International coral reef Symposium 2, 3-30.

SWAN, B. (1982) : The coastal geomorphology of Sri Lanka - an introductory survey. Univ. of New England, 182p.

\title{
ニュージーランドにおける現生および第三系産単体サンゴの \\ 種内変異に関する基礎的研究
}

\author{
森啓* \\ Intraspecific Variations of Recent and Tertiary Solitary \\ Corals from New Zealand
}

Kei MORI

\section{I. はじめに}

これまで，多くの現生および化石単体六放サン ゴが報告されてきているが，それぞれの種の提唱 にあたって，あつかわれている個体数は，一般に きわめて少ない。このことは, 種の識別にあたっ
て，骨格形質の種内の変異を十分検討できないま ま，類型分類が行われ，種の細分化が進められて きたことを示している。分類にあたって,骨格形質 の種内変異の重要性は, 以前から指摘されてきた ものの，その解明を可能にする資料が不足してい たのが実状である。MORI and MINOURA(1983)

*. 東北大学理学部 Institute of Geology and Paleontology, Tohoku University 